\title{
16. THE NATURE, ORIGIN, AND DISTRIBUTION OF ORGANIC MATERIAL AT DEEP SEA DRILLING SITES 482 THROUGH 485, LEG 65, IN THE GULF OF CALIFORNIA ${ }^{1}$
}

\author{
G. Deroo and J. P. Herbin, Institut Français du Pétrole, 1 et 4 avenue de Bois Préau, 92500 Rueil-Malmaison, France
}

\begin{abstract}
Pliocene-Pleistocene marls, muds, and hemipelagic clays with some beds of silt and sand were recovered on Leg 65 near the crest of the East Pacific Rise at the mouth of the Gulf of California. The organic matter in the sediments is mainly of marine origin for the upper Pleistocene sediments (0-0.61 m.y.), while the lower Pleistocene deposits ( $0.61-$ 1.80 m.y.) are characterized by continental organic matter except near the bottom of the sediment section in Hole $483 \mathrm{~A}$, where marine organic matter was found. The sediments belong to an early stage of geochemical evolution, except in Hole 482D, where hydrothermal effects are invoked to explain the maturity of the organic matter above the basement.
\end{abstract}

\section{INTRODUCTION}

The Gulf of California represents an unusual, endmember geologic environment characterized by rapid deposition of mixed continental and marine sediments in a young ocean basin displaying an anomalously high heat flow. The purpose of this study is to determine the distribution, origin, and maturity of organic material in the Pleistocene sediments cored across the mouth of this basin during Deep Sea Drilling Project (DSDP) Leg 65 at Sites 482 through 485 (Fig. 1). For this purpose, organic carbon and pyrolysis analyses were carried out on 127 samples from Holes 482A, B, and D; Holes 483A and $483 \mathrm{C}$; Hole 484A; and Holes 485 and $485 \mathrm{~A}$. Although these analyses are sufficient to characterize the organic material at the sites from a geochemical standpoint, complete analyses could not be performed because of limitations of sample size.

\section{Sampling}

Fifty upper Pleistocene samples were collected from the 137 meters of sediment cored above the basement in Holes 482A, B, and D. As can be seen in Figure 2, the sediments consist predominantly of hemipelagic clay to silty clay with traces of biogenic materials and rare, fine-grained turbidites of silty sand.

An additional 34 samples were collected from Holes 483 , B, and C. As noted in the Site 483 report (this volume), the sediments at this site may be divided into three units, all of them Pleistocene: Unit I (0-36.5 m) consists of nannofossil marl, radiolarian ooze, and clayey silt. These grade into Unit II (36.5-52 m), which consists of biogenic marls and muds grading into a silty sand turbidite. This, in turn, grades into Unit III (52-109 m), which consists of hemipelagic silty clay and clayey silt.

In Hole 484A, 13 samples were collected from a 50meter section composed of hemipelagic clay with interlayered beds of clayey silt and varved mud, containing diatoms, radiolarians, and sponge spicules.

\footnotetext{
${ }^{1}$ Lewis, B. T. R., Robinson, P., et al., Init. Repts. DSDP, 65: Washington (U.S. Govt. Printing Office)
}

Thirty more samples were collected from the 153 meters of sediment cored above the basement in Holes 485 and $485 \mathrm{~A}$, and a final sample was collected within the basement at a depth of 208 meters. Two units, both Pleistocene in age, were recognized in the sediments overlying the basement: The upper unit $(0-79 \mathrm{~m})$ consists of hemipelagic clay with occasional layers of silt, while the lower unit $(79-153 \mathrm{~m})$ consists of hemipelagic clay enriched in clayey silt and silty sand.

\section{ANALYTICAL PROCEDURES}

The organic carbon content of the samples was measured using standard LECO apparatus, after which a pyrolysis assay was conducted using a Rock-Eval source rock analyzer. The pyrolysis method described by Espitalié et al. (1977) using the Rock-Eval apparatus allows three types of kerogen to be defined, which can be used to characterize the organic matter in ancient sediments (Tissot et al., 1974). When young and largely immature material is considered, as in the present case, the reference paths I, II, and III for kerogens can be used under appropriate conditions. Oxygenated molecules are common in a very immature organic matter and cause the oxygen index (OI) to be high after pyrolysis. As diagenesis increases with increasing age and depth of burial, defunctionalization modifies the organic matter, causing the oxygen index to decrease to the range shown by the reference paths for ancient kerogens. As observed for the Pleistocene and Pliocene material recovered on Leg 64 (Deroo et al., in press), the change in the oxygen index is important for organic matter belonging to types I and II. The change in the hydrogen index (HI), on the other hand, is low.

The pyrolysis analyses are also used to define the maturity of the organic matter in the sediments. The temperature corresponding to the top of the pyrolysis peak, for example, may be used to determine whether maturation occurred in the immature oil zone between 400 and $440^{\circ} \mathrm{C}$, the main oil (or mature) zone from 440 to $460^{\circ} \mathrm{C}$, or the cracking (or gas) zone beyond $460^{\circ} \mathrm{C}$.

\section{INORGANIC AND ORGANIC CARBON}

A low inorganic carbon content ( 0.60 to $1.88 \mathrm{wt} . \%)$, corresponding to 5 to $16 \mathrm{wt} . \%$ calcium carbonate, was found in most of the samples recovered on Leg 65, with only three samples showing values approaching or exceeding $20 \%$ (Table 1). The organic carbon content, on the other hand, was relatively high, ranging from 1.3 to 3 wt. $\%$ in Hole 482B; 2 to 3 wt. $\%$ in Holes $482 \mathrm{~A}$ and D; 1 to 2.5 wt. $\%$ in Holes $483, \mathrm{~B}$, and C; 2 to 4 wt. $\%$ in Hole $484 \mathrm{~A}$; and 1.5 to $3 \mathrm{wt} . \%$ in most of the samples 


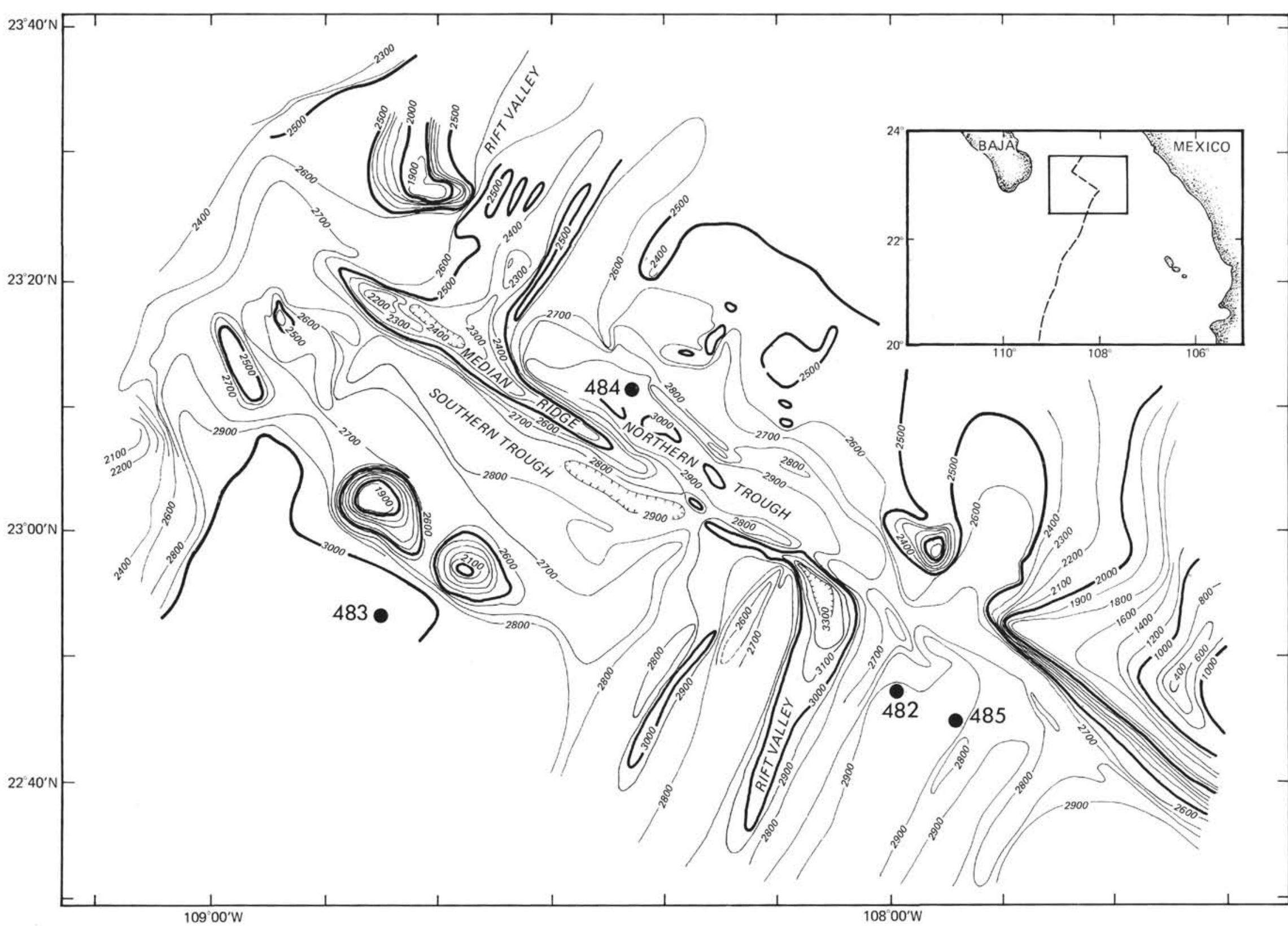




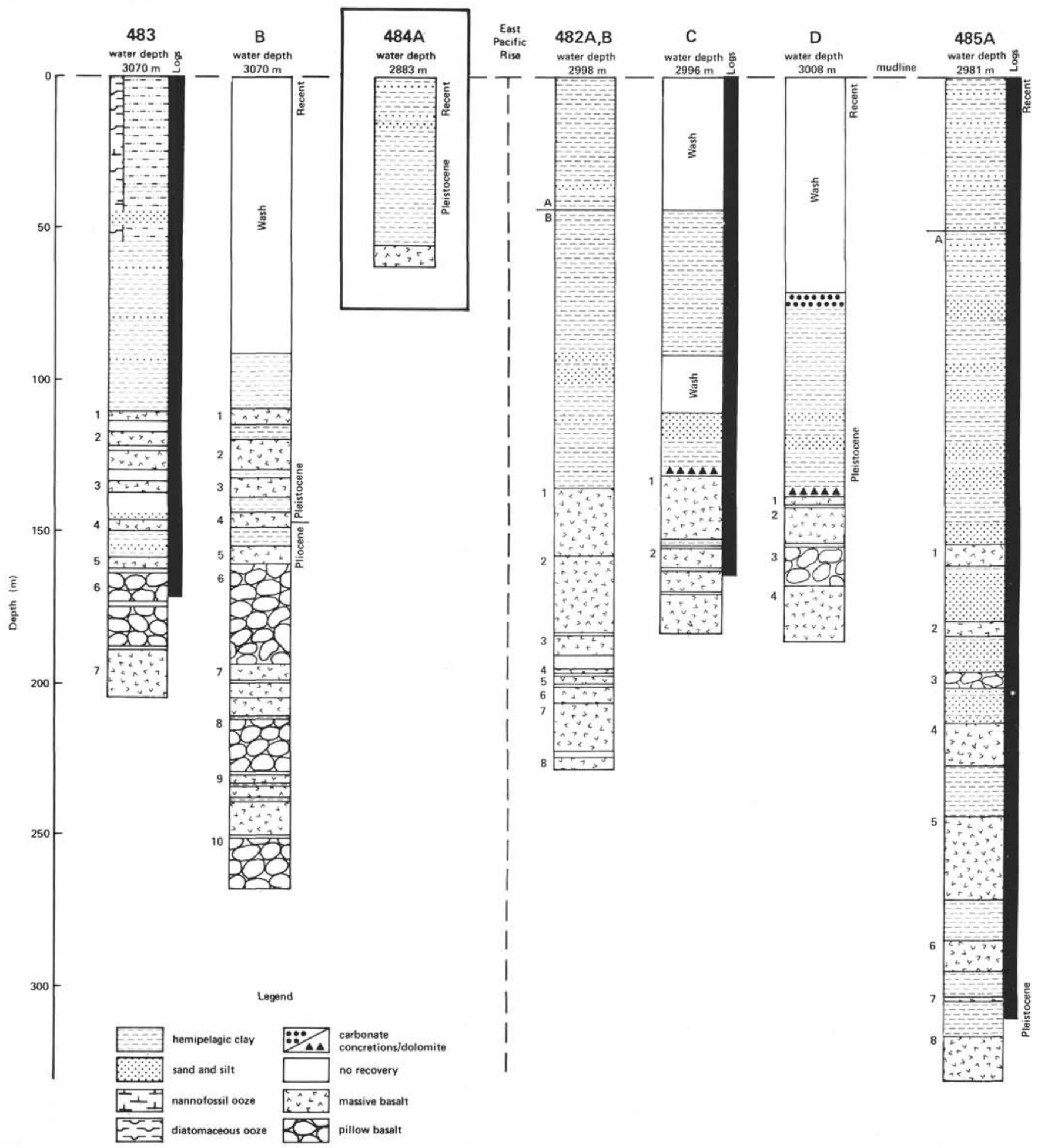

Figure 2. Stratigraphic columns for sites drilled on Leg 65 .

from Holes 485 and $485 \mathrm{~A}$. Comparable values were found in the samples recovered on Leg 64 in the Cabo San Lucas area (Deroo et al., in press).

\section{MATURITY OF ORGANIC MATTER}

The pyrolysis temperatures of the samples from Hole $484 \mathrm{~A}$ range from 416 to $425^{\circ} \mathrm{C}$ throughout the sediment section. Similarly, the temperatures range from 418- $425^{\circ} \mathrm{C}$ at the top to $423-431^{\circ} \mathrm{C}$ at the bottom of the sections in most of the holes drilled at Sites 482,483 , and 485 . These temperatures indicate that most of the organic matter recovered is immature.

In Hole 482D, however, a temperature range of 432 to $439^{\circ} \mathrm{C}$ was observed for the sediments between Sections 482D-5-1 and 482D-6-3. This temperature range is close to that of the main oil genesis zone, and a pro- 
Table 1. Organic geochemistry of sediments recovered on Leg 65 .

\begin{tabular}{|c|c|c|c|c|c|c|c|c|}
\hline $\begin{array}{c}\text { Sample } \\
\text { (interval in } \mathrm{cm} \text { ) }\end{array}$ & $\begin{array}{l}\text { Sub-bottom } \\
\text { Depth } \\
\text { (m) }\end{array}$ & $\begin{array}{l}\text { Inorganic } \\
\text { Carbon }^{\mathrm{a}} \\
\text { (wt. \%) }\end{array}$ & $\begin{array}{l}\text { Organic } \\
\text { Carbon } \\
\text { (wt. } \% \text { ) }\end{array}$ & $\begin{array}{l}\text { Hydrogen } \\
\text { Index }\end{array}$ & $\begin{array}{l}\text { Oxygen } \\
\text { Index }\end{array}$ & $\begin{array}{l}\text { Hydrogegn } \\
\text { Index }\end{array}$ & $\begin{array}{l}\text { Oxygen } \\
\text { Index }\end{array}$ & $\begin{array}{c}\text { Pyrolysis } \\
\text { Temperature } \\
\left({ }^{\circ} \mathrm{C}\right)\end{array}$ \\
\hline \multicolumn{9}{|l|}{ Hole 482} \\
\hline $1-1,58-60$ & 0.58 & 1.2 & 3.03 & 282 & 246 & 8.56 & 7.46 & 424 \\
\hline $1-3,58-60$ & 3.58 & 1.1 & 2.60 & 265 & 209 & 5.36 & 5.43 & 423 \\
\hline \multicolumn{9}{|l|}{ Hole $482 \mathrm{~A}$} \\
\hline $1-1,90-92$ & 0.90 & 2.2 & 2.15 & 249 & 346 & 6.89 & 7.44 & 423 \\
\hline $1-3,90-92$ & 3.90 & 1.1 & 2.61 & 262 & 212 & 6.83 & 5.54 & 424 \\
\hline $2-1,90-92$ & 6.90 & 1.1 & 2.41 & 271 & 222 & 6.52 & 5.34 & 420 \\
\hline $2-3,90-92$ & 9.90 & 1.1 & 3.16 & 350 & 220 & 11.07 & 6.96 & 425 \\
\hline $2-6,90-92$ & 14.40 & 1.2 & 2.63 & 285 & 205 & 7.49 & 5.39 & 424 \\
\hline $3-1,90-92$ & 16.40 & 1.2 & 2.57 & 268 & 174 & 6.89 & 4.48 & 421 \\
\hline $4-1,90-92$ & 25.90 & 1.2 & 2.84 & 309 & 183 & 8.77 & 5.19 & 422 \\
\hline $4-3,90-92$ & 28.90 & 1.1 & 2.90 & 297 & 178 & 8.61 & 5.16 & 424 \\
\hline $4-6,90-92$ & 33.40 & 1.1 & 2.08 & 257 & 172 & 5.34 & 3.57 & 426 \\
\hline $5-1,90-92$ & 35.40 & 1.1 & 1.49 & 185 & 164 & 2.75 & 2.45 & 423 \\
\hline $5-3,90-92$ & 38.40 & 1.2 & 1.20 & 128 & 169 & 1.53 & 2.03 & 422 \\
\hline $5-6,100-102$ & 40.00 & 0.7 & 3.24 & 371 & 126 & 12.04 & 4.07 & 427 \\
\hline \multicolumn{9}{|l|}{ Hole 482B } \\
\hline $1-1,90-92$ & 44.90 & 0.7 & 1.57 & 145 & 152 & 2.28 & 2.39 & 425 \\
\hline $1-3,100-102$ & 48.00 & 1.0 & 1.54 & 174 & 163 & 2.68 & 2.51 & 423 \\
\hline $2-1,90-92$ & 54.40 & 1.2 & 2.22 & 263 & 150 & 5.84 & 3.34 & 425 \\
\hline $2-3,90-92$ & 57.40 & 1.2 & 2.41 & 237 & 135 & 5.71 & 3.25 & 426 \\
\hline $2-5,90-92$ & 60.40 & 1.1 & 2.05 & 226 & 168 & 4.63 & 3.45 & 428 \\
\hline $4-1,90-92$ & 73.40 & 1.3 & 2.32 & 239 & 163 & 5.53 & 3.79 & 427 \\
\hline $4-3,90-92$ & 76.40 & 1.2 & 2.44 & 204 & 137 & 4.99 & 3.35 & 428 \\
\hline $5-1,90-92$ & 82.90 & 1.0 & 2.38 & 187 & 146 & 4.46 & 3.47 & 426 \\
\hline $5-3,70-72$ & 85.70 & 1.3 & 2.41 & 206 & 130 & 4.97 & 3.14 & 427 \\
\hline $6-1,90-92$ & 92.40 & 1.0 & 1.49 & 167 & 121 & 2.49 & 1.80 & 426 \\
\hline $6-3,90-92$ & 95.40 & 1.2 & 1.84 & 171 & 121 & 3.15 & 2.23 & 427 \\
\hline $6-6,90-92$ & 99.90 & 1.0 & 1.32 & 138 & 121 & 1.82 & 1.60 & 426 \\
\hline $7-2,78-80$ & 403.28 & 1.1 & 2.56 & 211 & 116 & 5.40 & 2.98 & 427 \\
\hline $8-1,90-92$ & 111.40 & 1.0 & 2.29 & 194 & 126 & 4.44 & 2.89 & 429 \\
\hline $8-3,90-92$ & 114.40 & 1.0 & 2.21 & 194 & 118 & 4.27 & 2.61 & 424 \\
\hline $9-1,90-92$ & 120.90 & 0.6 & 2.98 & 262 & 75 & 7.81 & 2.24 & 423 \\
\hline $9-3,90-92$ & 123.90 & 0.6 & 3.12 & 258 & 68 & 8.06 & 2.13 & 424 \\
\hline $9 \cdot 6,90-92$ & 128.40 & 1.0 & 2.58 & 223 & 90 & 5.75 & 2.31 & 424 \\
\hline $10-1,90-92$ & 130.40 & 0.8 & 2.82 & 241 & 90 & 6.78 & 2.54 & 431 \\
\hline $10-3,90-92$ & 133.40 & 0.9 & 2.49 & 235 & 92 & 5.85 & 2.30 & 423 \\
\hline $10-6,90-92$ & 137.90 & 0.9 & 2.56 & 237 & 74 & 6.07 & 1.90 & 423 \\
\hline
\end{tabular}

1-1, 90-92

$1-3,90-92$
$1-6,90-92$

2-1, 90-9

2-3, 90-9

$3-1,90-92$

$3-3,90-92$

3-6, 90-92

4-1, 90-92

4-3, 66-68

5-1, 90-92

6-1, 90-92

6-3, 96-98

$7-1,90-92$

$7-3,90-92$

(1)

0.9

$\begin{array}{lll}72.40 & 0.9 & 3.16 \\ 75.40 & 1.0 & 3.17 \\ 79.90 & 0.9 & 3.08 \\ 81.90 & 1.1 & 2.27 \\ 84.90 & 1.1 & 2.19 \\ 91.40 & 1.2 & 2.47 \\ 94.40 & 1.2 & 2.43 \\ 98.90 & 1.4 & 2.45 \\ 100.90 & 1.2 & 3.24 \\ 103.66 & 1.2 & 2.39 \\ 110.40 & 1.2 & 2.35 \\ 119.90 & 1.0 & 2.86 \\ 122.96 & 1.0 & 2.66 \\ 129.40 & 1.3 & 2.29 \\ 132.40 & 1.2 & 2.26\end{array}$

$\begin{array}{rrrrr}260 & 111 & 8.23 & 3.50 & 427 \\ 281 & 115 & 8.92 & 3.63 & 426 \\ 279 & 118 & 8.60 & 3.63 & 424 \\ 194 & 124 & 4.41 & 2.81 & 426 \\ 187 & 116 & 4.08 & 2.54 & 425 \\ 168 & 93 & 4.16 & 2.29 & 427 \\ 178 & 92 & 4.32 & 2.23 & 425 \\ 177 & 85 & 4.35 & 2.09 & 427 \\ 217 & 64 & 7.05 & 2.06 & 424 \\ 194 & 80 & 4.64 & 1.91 & 428 \\ 169 & 77 & 3.98 & 1.81 & 432 \\ 176 & 44 & 5.04 & 1.27 & 436 \\ 158 & 41 & 4.21 & 1.10 & 439 \\ 18 & 45 & 1.40 & 1.04 & - \\ 3 & 35 & 0.06 & 0.78 & -\end{array}$

Hole 483A

$2-1,90-92$

$2-3,90-92$
$3-1,90-92$

$3-3,90-92$

4-1, 90-9

4-3, 90-9

5-1, 90-92

$5-3,90-9$

6-1, 90-92

$6-3,90-92$

$7-1,90-92$

$7-3,90-92$

8-1, 90-92

$8-3,90-92$

$9-1,90-92$

$9-1,90-92$

$9-3,90-92$

9-6, 90-92

$10-1,90-92$

$11-1,90-92$

$11-3,90-92$

$13-1,90-92$

$13-3,60-62$

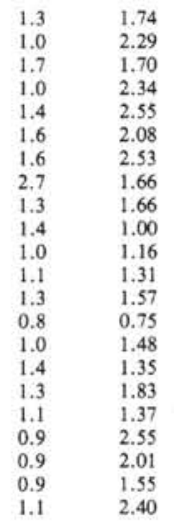

$\begin{array}{rrrrr}144 & 248 & 2.50 & 4.31 & 424 \\ 232 & 194 & 5.31 & 4.44 & 424 \\ 155 & 296 & 2.63 & 5.04 & 420 \\ 251 & 166 & 5.88 & 3.88 & 422 \\ 239 & 200 & 6.09 & 5.09 & 421 \\ 167 & 219 & 3.48 & 4.56 & 417 \\ 237 & 209 & 6.00 & 5.30 & 420 \\ 170 & 278 & 2.82 & 4.62 & 419 \\ 132 & 245 & 2.19 & 4.07 & 422 \\ 61 & 291 & 0.62 & 2.91 & 415 \\ 130 & 200 & 1.50 & 2.32 & - \\ 92 & 240 & 1.20 & 3.14 & 419 \\ 66 & 192 & 1.03 & 3.02 & 412 \\ 45 & 128 & 0.34 & 0.96 & 424 \\ 65 & 139 & 0.97 & 2.06 & 421 \\ 55 & 284 & 0.74 & 3.84 & 414 \\ 95 & 185 & 1.75 & 3.38 & 419 \\ 49 & 200 & 0.68 & 2.74 & 419 \\ 151 & 105 & 3.85 & 2.68 & 427 \\ 95 & 141 & 1.91 & 2.84 & 426 \\ 82 & 68 & 1.28 & 1.06 & 420 \\ 110 & 52 & 2.63 & 1.25 & 431\end{array}$

Hole 483B

4.90

11.40
14.40

20.90

23.90

30.40

33.40

39.90

42.90
49.40

52.40

52.40
58.90

61.90

61.90

68.40

71.40

75.90

77.90

90.40

106.40

109.10

1.74
2.29
1.70
2.34
2.55
2.08
2.53
1.66
1.66
1.00
1.16
1.31
1.57
0.75
1.48
1.35
1.83
1.37
2.55
2.01
1.55
2.40

$\begin{array}{ll}1-1,85-87 & 92.37 \\ 1-3,85-87 & 95.37\end{array}$

$1-3,85-87$
$2-1,90-92$

$2-3,90-92$

92.37
95.37
101.9
104.9

$\begin{array}{ll}0.8 & 1.73 \\ 1.0 & 1.70 \\ 0.8 & 1.42 \\ 0.8 & 1.29\end{array}$

109.40

$\begin{array}{ll}0.9 & 2.18\end{array}$

$\begin{array}{lllll}79 & 126 & 1.37 & 2.18 & 424 \\ 72 & 172 & 1.23 & 2.93 & 421 \\ 83 & 110 & 1.18 & 1.56 & 404 \\ 43 & 143 & 0.55 & 1.84 & - \\ 85 & 111 & 1.85 & 2.41 & 426\end{array}$


Table 1. (Continued).

\begin{tabular}{|c|c|c|c|c|c|c|c|c|}
\hline $\begin{array}{c}\text { Sample } \\
\text { (interval in } \mathrm{cm} \text { ) }\end{array}$ & $\begin{array}{l}\text { Sub-bottom } \\
\text { Depth } \\
\text { (m) }\end{array}$ & $\begin{array}{l}\text { Inorganic } \\
\text { Carbona }^{\mathrm{a}} \\
\text { (wt.\%) }\end{array}$ & $\begin{array}{l}\text { Organic } \\
\text { Carbon } \\
\text { (wt.\%) }\end{array}$ & $\begin{array}{l}\text { Hydrogen } \\
\text { Index }\end{array}$ & $\begin{array}{l}\text { Oxygen } \\
\text { Index }\end{array}$ & $\begin{array}{l}\text { Hydrogen } \\
\text { Index }\end{array}$ & $\begin{array}{l}\text { Oxygen } \\
\text { Index }\end{array}$ & $\begin{array}{c}\text { Pyrolysis } \\
\text { Temperature } \\
\left({ }^{\circ} \mathrm{C}\right)\end{array}$ \\
\hline \multicolumn{9}{|l|}{ Hole $483 \mathrm{C}$} \\
\hline $1-1,90-92$ & 39.40 & 1.0 & 1.35 & 90 & 236 & 1.22 & 3.18 & 416 \\
\hline $1-3,90-92$ & 42.40 & 1.3 & 1.37 & 87 & 245 & 1.20 & 3.36 & 412 \\
\hline $2-1,90-92$ & 86.90 & 1.3 & 2.33 & 44 & 159 & 1.03 & 3.70 & 410 \\
\hline $2-3,90-92$ & 89.90 & 1.0 & 1.76 & 77 & 188 & 1.36 & 3.30 & 412 \\
\hline $2-6,90-92$ & 94.40 & 1.1 & 1.27 & 60 & 209 & 0.76 & 2.65 & 415 \\
\hline $3-1,90-92$ & 96.40 & 0.8 & 1.59 & 64 & 139 & 1.02 & 2.21 & 416 \\
\hline $4-1,90-92$ & 105.90 & 0.9 & 1.70 & 67 & 126 & 1.14 & 2.15 & 422 \\
\hline \multicolumn{9}{|l|}{ Hole $484 \mathrm{~A}$} \\
\hline $1-1,90-92$ & 0.90 & 1.2 & 2.60 & 252 & 234 & 6.56 & 6.09 & 421 \\
\hline $1-3,90-92$ & 3.90 & 1.2 & 2.99 & 300 & 196 & 8.98 & 5.85 & 416 \\
\hline $2-1,90-92$ & 8.90 & 1.0 & 3.12 & 272 & 185 & 8.50 & 5.78 & 425 \\
\hline $2-3,90-92$ & 11.90 & 1.4 & 2.30 & 157 & 209 & 3.62 & 4.80 & 424 \\
\hline $3-1,90-92$ & 13.40 & 1.3 & 3.25 & 124 & 155 & 4.03 & 5.03 & 416 \\
\hline $3-3,90-92$ & 21.40 & 1.5 & 2.73 & 197 & 181 & 5.39 & 4.93 & 420 \\
\hline $3-6,70-72$ & 25.70 & 0.9 & 3.33 & 219 & 155 & 7.28 & 5.15 & 418 \\
\hline $4-1,90-92$ & 27.90 & 2.4 & 3.50 & 248 & 206 & 8.78 & 7.21 & 418 \\
\hline $4-3,90-93$ & 30.90 & 1.2 & 3.94 & 275 & 172 & 10.83 & 6.77 & 416 \\
\hline $5-1,90-92$ & 37.40 & 1.2 & 3.96 & 252 & 151 & 9.98 & 5.97 & 416 \\
\hline $5-3,90-92$ & 40.40 & 1.1 & 3.09 & 237 & 169 & 7.32 & 5.21 & 418 \\
\hline $6-1,90-92$ & 46.90 & 1.8 & 2.05 & 144 & 228 & 2.96 & 4.68 & 418 \\
\hline $6-3,90-92$ & 49.90 & 1.8 & 2.80 & 199 & 215 & 5.63 & 6.01 & 422 \\
\hline \multicolumn{9}{|l|}{ Hole 485} \\
\hline $1-1,90-92$ & 0.90 & 1.4 & 2.81 & 223 & 252 & 6.28 & 7,07 & 418 \\
\hline $2-1,90-92$ & 3.90 & 0.8 & 1.08 & 102 & 170 & 1.11 & 1.84 & 420 \\
\hline $2-3,90-92$ & 6.90 & 1.0 & 1.62 & 104 & 249 & 1.69 & 4.04 & 419 \\
\hline $3-1,90-92$ & 13.40 & 0.8 & 3.34 & 285 & 122 & 9.51 & 4.09 & 420 \\
\hline $3-3,90-92$ & 16.40 & 1.0 & 1.02 & 90 & 163 & 0.92 & 1.66 & 419 \\
\hline $3 \cdot 6,90-92$ & 20.90 & 1.0 & 2.84 & 217 & 156 & 6.17 & 4.42 & 422 \\
\hline $4-1,90-92$ & 22.90 & 1.2 & 2.09 & 155 & 164 & 3.25 & 3.42 & 423 \\
\hline $4-3,60-68$ & 25.40 & 0.9 & 3.14 & 248 & 133 & 7.79 & 4.19 & 420 \\
\hline $5-1,90-92$ & 32.40 & 1.1 & 2.62 & 206 & 148 & 5.41 & 3.87 & 419 \\
\hline $5-3,90-92$ & 35.40 & 0.9 & 2.27 & 128 & 147 & 2.91 & 3.33 & 420 \\
\hline $6-1,90-92$ & 41.90 & 1.1 & 2.57 & 168 & 141 & 4.31 & 3.62 & 420 \\
\hline $6-3,90-92$ & 44.90 & 1.0 & 2.42 & 92 & 130 & 2.23 & 3.15 & 421 \\
\hline $6 \cdot 6,90-92$ & 49.40 & 1.1 & 1.68 & 59 & 92 & 0.98 & 1.55 & 425 \\
\hline \multicolumn{9}{|l|}{ Hole 485A } \\
\hline $1-1,90-92$ & 51.40 & 0.8 & 3.09 & 195 & 127 & 6.01 & 3.91 & 424 \\
\hline $1-3,90-92$ & 54.40 & 0.9 & 3.00 & 199 & 132 & 5.97 & 3.97 & 425 \\
\hline $1 \cdot 6,90-92$ & 57.90 & 1.1 & 2.11 & 132 & 154 & 2.79 & 3.24 & 426 \\
\hline $2-1,90-92$ & 60.90 & 1.0 & 2.51 & 152 & 133 & 3.83 & 3.34 & 424 \\
\hline $2-3,90-92$ & 63.90 & 1.1 & 2.46 & 156 & 146 & 3.85 & 3.59 & 426 \\
\hline $3-1,90-92$ & 70.40 & 1.0 & 2.28 & 144 & 150 & 3.29 & 3.42 & 422 \\
\hline $4-1,90-92$ & 79.90 & 1.0 & 2.69 & 189 & 128 & 5.10 & 3.43 & 422 \\
\hline $5-1,90-92$ & 89.40 & 1.0 & 2.49 & 182 & 122 & 4.54 & 3.05 & 424 \\
\hline $5-3,90-92$ & 92.40 & 1.2 & 1.50 & 82 & 127 & 1.23 & 1.91 & 425 \\
\hline $6-1,90-92$ & 98.90 & 1.2 & 1.44 & 100 & 136 & 1.44 & 1.96 & 425 \\
\hline $6-3,90-92$ & 101.90 & 1.1 & 0.50 & 57 & 182 & 0.29 & 0.91 & 451 \\
\hline $7-1,90-92$ & 108.40 & 0.9 & 0.67 & 65 & 163 & 0.44 & 1.09 & 434 \\
\hline $8-1,90-92$ & 117.90 & 1.2 & 1.34 & 92 & 140 & 1.24 & 1.88 & 430 \\
\hline $9-1,90-92$ & 127,40 & 1.2 & 1.54 & 100 & 135 & 1.55 & 2.08 & 423 \\
\hline $10-1,90-92$ & 136.90 & 0.9 & 1.49 & 75 & 121 & 1.12 & 1.81 & 421 \\
\hline $11-1,90-92$ & 146.40 & 0.9 & 1.60 & 114 & 118 & 1.83 & 1.89 & 423 \\
\hline $22-5,106-109$ & 208.56 & 0.9 & 2.17 & 84 & 103 & 1.81 & 2.24 & 421 \\
\hline
\end{tabular}

${ }^{a}$ Multiply by 8.33 to determine equivalent wt. $\% \mathrm{CaCO}_{3}$.

${ }^{b}$ Milligrams hydrocarbon per gram organic carboh.

c Milligrams carbon dioxide per gram organic carbon.

Milligrams hydrocarbon per gram rock.

e Milligrams carbon dioxide per gram rock.

gressive enrichment in free hydrocarbons is observed which ranges from $4 \%$ of the total pyrolysis hydrocarbon production in Section 482D-5-1 to $76 \%$ and $95 \%$ in Sections 482D-7-1 and 7-3, respectively. Such a large production of free hydrocarbons only occurs when kerogen reaches the maturation zone. Since an in situ temperature of about $90^{\circ} \mathrm{C}$ was estimated for the sediment/ basement contact (Site 482 report, this volume), advanced maturation is likely at the same depth in Hole $482 \mathrm{C}$.

\section{NATURE OF ORGANIC MATTER}

At Site 482, the hydrocarbon index data indicate that most of the organic matter in the sediments is immature and belongs to Marine Type II (Figs. 3A and 3B). A sig- nificant decrease in the oxygen index was observed in a 20-meter-thick layer overlying the basement in Hole 482B and in Hole 482D between Sections 2-1 and 6-3. This can be explained by the defunctionalization of oxygenated molecules during diagenesis. As noted previously, the samples from Sections 482D-7-1 and 7-3 display very low hydrogen index values (18 and 3 , respectively) as a result of kerogen maturation associated (tentatively) with hydrothermal alteration in the sediments overlying the basalts.

Four populations of organic matter are present in Hole 483 (Fig. 3C). These include: (1) immature material of Marine Type II in Sections 483-2-1 through 7-1 $(\mathrm{HI}=130-251 ; \mathrm{OI}=166-296)$; $(2)$ organic matter of undetermined origin occurring with turbidites in Sec- 

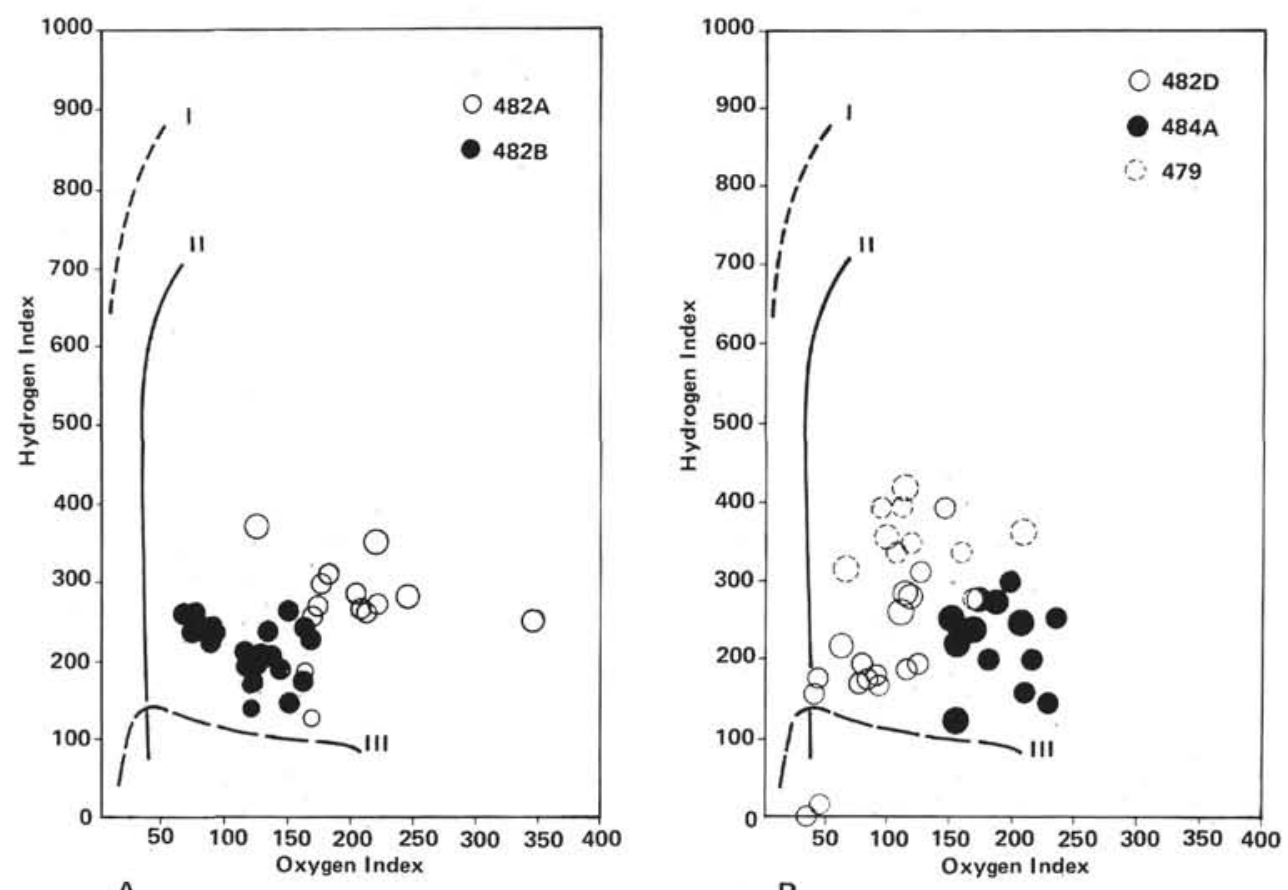

A

B
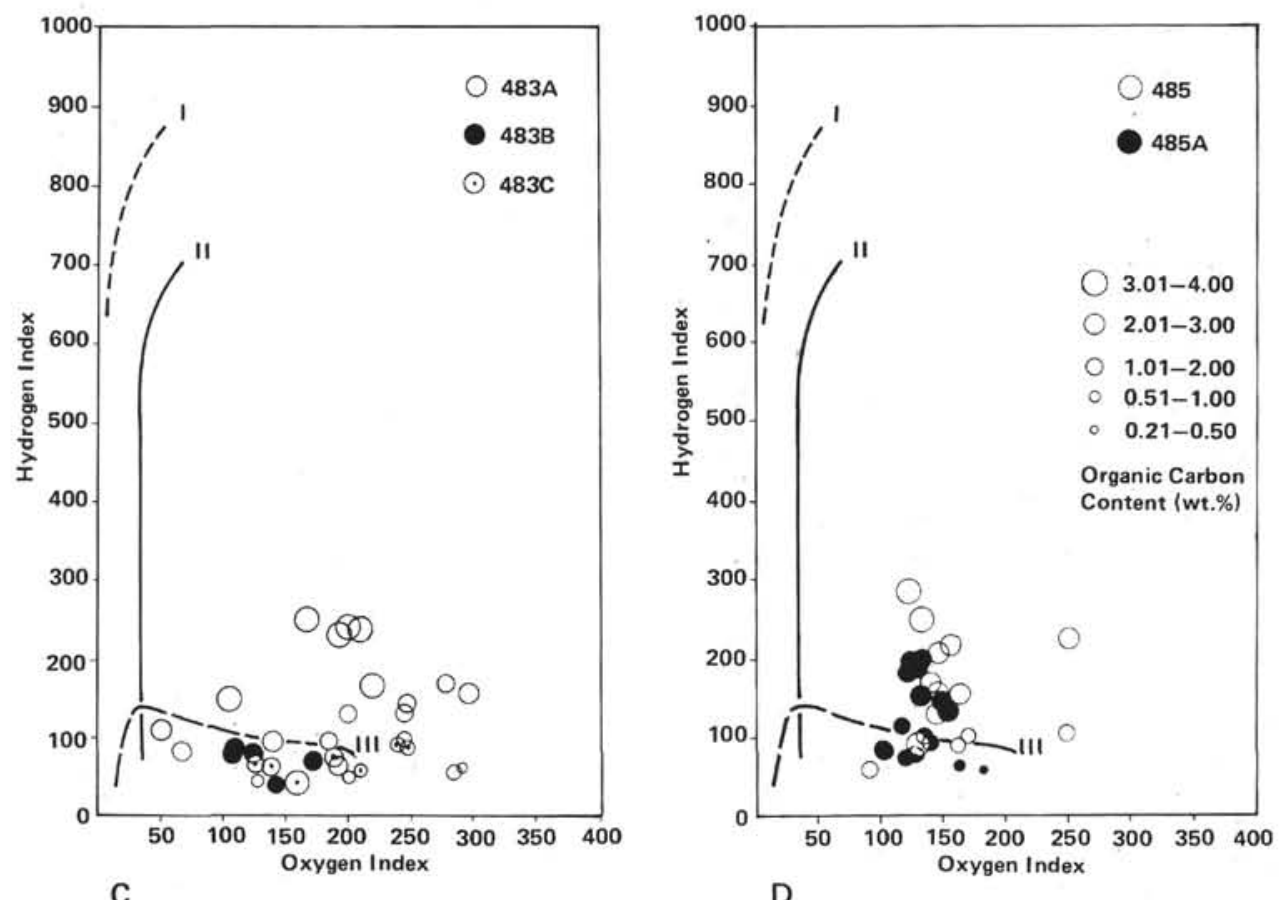

Figure 3. Hydrogen index vs. oxygen index for: A. Holes 482A and B; B. Holes 482D, 484A, and Site 479 (drilled on Leg 64); C. Holes 483, B, and C; and D. Holes 485 and 485A.

tions 483-6-3, 7-3, and 9-3 $(\mathrm{HI}=55-92 ; \mathrm{OI} \geq 240)$; (3) immature material of Continental Type III in Sections 483-8-1 through 11-3 $(\mathrm{HI}=55-151 ; \mathrm{OI}=185-284)$; and (4) more mature marine organic material overlying the basement in Sections 483-11-1, 13-1, and 13-3 (HI = 82151; OI $=52-105$ ). In Holes 483B and C, the organic matter in the 20 meters of sediment overlying the basement consists predominantly of continental material of Type III.
In Hole 484A (Fig. 3B) the pyrolysis data are again consistent with the presence of very immature organic material of Marine Type II $(\mathrm{HI}=124-300$; OI $=151$ 234). A comparison with sediments from Site 479 in the Guaymas Basin shows that samples of equivalent age (0-0.44 m.y.) from Sections 479-3-2 through 34-6 contain equivalent organic carbon contents: $2.4-3.3$ vs. 2.6$3.9 \mathrm{wt} . \%$ for Site 484 . The high hydrogen index and low oxygen index values observed at Site 479 (Fig. 3B) prob- 
ably result from better preservation of the organic matter in the depositional environment of the Guaymas Basin compared to the mouth of the Gulf.

In Holes 485 and $485 \mathrm{~A}$ (Fig. 3D) two populations of organic matter can be defined on the basis of the hydrogen index values, namely immature marine material of Type II in Sections 485-1-1 through 485A-5-1 (HI $\geq 102$; $\mathrm{OI} \geq 122$ ) and continental material of Type III in Sections 485-3-3, 6-3, and 6-6. The interval from Sections 485A-5-3 through 11-1 above the basement and the sediment sample taken from Section 485A-22-5 within the basement also contain continental organic matter of Type III.

\section{VERTICAL DISTRIBUTION AND ORIGIN OF ORGANIC MATTER}

From the preceding discussion and the chronologic horizons shown in Table 2 and Figure 4, it is clear that the sediments recovered in Holes 482A, B, and D and Hole $484 \mathrm{~A}$ correspond to a marine organic sequence deposited on or just above the basement between 0.44 m.y. ago and the present. The same marine organic matter extends to $0.61 \mathrm{~m} . \mathrm{y}$. in both Holes $483 \mathrm{~A}$ and $485 \mathrm{~A}$.

In the holes drilled closer to land, however, the deeper sediments tend to contain organic material of continental origin. In Hole 485, for example, such material characterizes the 0.61 to $0.82 \mathrm{~m} . \mathrm{y}$. interval above the uppermost basalt as well as the sediments interlayered

Table 2. Chronologic horizons at Sites 482 through 485 .

\begin{tabular}{|c|c|c|c|c|c|c|c|c|}
\hline \multirow[b]{2}{*}{ Hole } & & \multirow[b]{2}{*}{0.25} & \multirow[b]{2}{*}{0.44} & \multicolumn{2}{|c|}{$\begin{array}{l}\text { Chronologic Horizon } \\
\left(\text { age in } \mathrm{m} . \mathrm{y}_{\mathrm{y}}\right)^{\mathrm{a}}\end{array}$} & \multirow[b]{2}{*}{1.04} & \multirow[b]{2}{*}{1.39} & \multirow[b]{2}{*}{1.80} \\
\hline & & & & 0.61 & 0.82 & & & \\
\hline 4828 & $\begin{array}{l}\text { Core-Section: } \\
\text { Depth }(m):\end{array}$ & $\begin{array}{l}5-3 \text { to } 6-1 \\
87\end{array}$ & $\begin{array}{c}14.2 \\
150\end{array}$ & & & & & \\
\hline $482 \mathrm{D}$ & $\begin{array}{l}\text { Core-Section: } \\
\text { Depth }(\mathrm{m}) \text { : }\end{array}$ & $\begin{array}{c}2-3 \text { to } 3-1 \\
87\end{array}$ & $\begin{array}{l}9 \text { to } 10 \\
150\end{array}$ & & & & & \\
\hline 483 & Core-Section: & 4.2 & 5.3 & $\begin{array}{l}6-5^{b} \\
46\end{array}$ & $8-1$ to 8.3 & $9-3$ to $9-6$ & $\begin{array}{c}11-1 \\
87\end{array}$ & $13-3$ \\
\hline $484 \mathrm{~A}$ & $\begin{array}{l}\text { Depth }(m): \\
\text { Core-Section: } \\
\text { Depth }(m):\end{array}$ & $\begin{array}{l}22 \\
3-6 \\
27\end{array}$ & $\begin{array}{l}34 \\
6-1 \\
46\end{array}$ & 46 & 60 & 72 & 87 & \\
\hline $485 \mathrm{~A}$ & $\begin{array}{l}\text { Core-Section: } \\
\text { Depth }(m) \text { : }\end{array}$ & $\begin{array}{c}3-6 \text { to } 4-1 \\
22\end{array}$ & $\begin{array}{l}6-1 \\
42\end{array}$ & $\begin{array}{c}5.1 \text { to } 5.3 \\
90\end{array}$ & $\begin{array}{l}11.1 \\
146\end{array}$ & $\begin{array}{l}22-5 \\
210\end{array}$ & & \\
\hline
\end{tabular}

a From site reports, this volume.

b Not recovered. between the basalts in Sections 485A-22-5 (about 1.04 m.y.). Continental organic material is also found in 0.61 to 1.39 m.y. old sediments in Hole 483 and in the $\leq 1.39$ $1.80 \mathrm{~m} . \mathrm{y}$. interval above the basement in Holes 483B and $483 \mathrm{C}$. Somewhat unexpectedly, however, the oldest sediments in Hole 483 contain organic material of marine origin.

\section{CONCLUSION}

The organic material in the sediments recovered at Sites 482 through 485 in the mouth of the Gulf of California belongs, for the most part, to an early stage of evolution. The only significant exception occurs in Hole $482 \mathrm{D}$, where hydrothermal effects accompanied by a high geothermal gradient can be invoked to explain the advanced maturation observed in the sediments immediately overlying the basement.

The organic matter examined is predominantly of marine origin in the upper Pleistocene sediments $(0 \leq 0.61$ m.y.) recovered at all four sites. With the exception of a thin layer of sediments overlying the basement in Hole 483 (which contains relatively mature organic material of marine origin), the middle and lower Pleistocene sediments (0.61 to 1.80 m.y.) recovered at Sites 483 and 485 contain organic material which is largely of continental origin. This pattern is consistent with early Pleistocene deposition in a narrow basin dominated by continental runoff, followed by sedimentation in a more open ocean environment during the upper Pleistocene.

\section{REFERENCES}

Deroo, G., Herbin, J. P., Roucaché, J., et al., in press. Geochemical and optical study of organic matter in some Pleistocene and Pliocene sediment from the Gulf of California: Leg 64, Holes 474481 A. In Curray, J. R., Moore, D. G., et al., Init. Repts. DSDP, 64: U.S. Govt. Printing Office (Washington, D.C.)

Espitalié, J., Laporte, J. L., Madec, M., et al., 1977. Méthode rapide de caractérisation des roches mères, de leur potentiel pétrolier et de leur degré d'évolution. Rev. Inst. Fr. Pet., 32:23-42.

Tissot, B., Durand, B., Espitalié, J., et al., 1974. Influence of thé nature and diagenesis of organic matter in the formation of petroleum. Am. Assoc. Petrol. Geol. Bull., 58:499-506. 
W

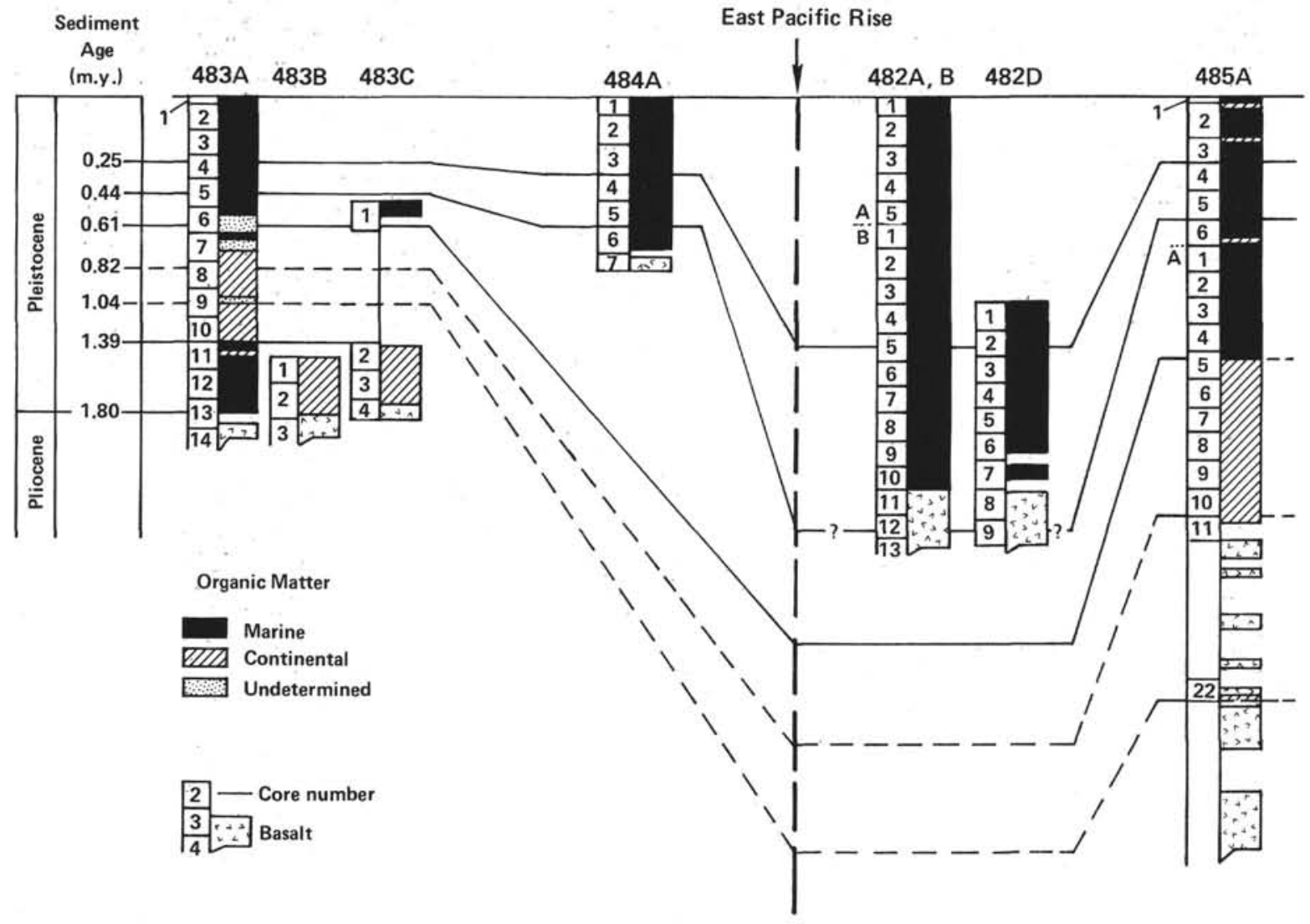

Figure 4. Vertical distribution and origin of organic material recovered in holes drilled on Leg 65.
E

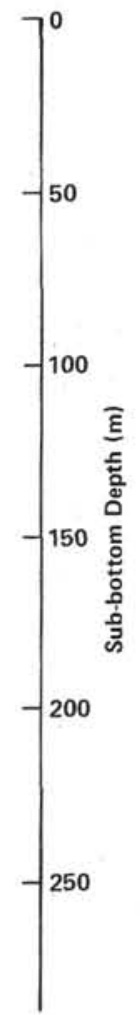

